\title{
PRELIMINARY GEOMECHANICAL ANALYSIS ON LIMESTONES IN PPSDM GEOMINERBA CAMPUS, PADALARANG, WEST JAVA
}

\author{
ANALISIS GEOMEKANIKA AWAL PADA BATUGAMPING DI \\ KAMPUS PPSDM GEOMINERBA, PADALARANG, JAWA BARAT
}

\author{
IRVAN SOPHIAN ${ }^{1}$, HERLINAWATI ${ }^{2}$, NUR KHOIRULLAH ${ }^{1}$, ABDURROKHIM ${ }^{1}$, IYAN \\ HARY ANTO $^{1}$ and HENDARMAWAN ${ }^{1}$ \\ ${ }^{1}$ Faculty of Geological Engineering, Padjadjaran University \\ Jalan Raya Bandung Sumedang KM 21, Jatinangor \\ Kabupaten Sumedang, Jawa Barat 45363 \\ e-mail : r.irvan.sophian@unpad.ac.id \\ 2 PPSDM GEOMINERBA \\ Jalan Jenderal Sudirman 623 Bandung 40211
}

\begin{abstract}
The research location is in the PPSDM Geominerba field campus. The campus is located in Padalarang, West Java that is surrounded by the open-pit mining of limestone and marble. This limestone was formed in Oligo-Miocene of Rajamandala Formation. The research objective was to determine the condition of the slopes around the campus based on geomechanical characteristics. Based on field observations, the slope angle in the area is dominated by steep slopes. The rock hardness level is dominated by hard rock with a hardness ranging from 50-100 MPa. Rock Mass Rating shows that the area is dominated by good rocks. While the Slope Mass Rating calculation show that the maximum slope angle is between $52-75^{\circ}$. Level of deformation and intensive weathering process will reduce the strength of the rock in the future. Several rock fall occurrences on this research area support this assumption. Yet, some local open pit mining area activity near the toe hill of the area need to be concerned regarding the effect of the local rock fall occurrences.
\end{abstract}

Keywords: rock mass rating, slope mass rating, limestone, Rajamandala Formation

\begin{abstract}
ABSTRAK
Lokasi penelitian berada di area kampus lapangan PPSDM Geominerba. Kampus ini berlokasi di Padalarang, Jawa Barat. Lokasi area dikelilingi oleh tambang terbuka batugamping dan marmer. Batugamping di lokasi ini merupakan bagian dari Formasi Rajamandala yang terbentuk pada umur OligoMiosen. Tujuan penelitian adalah untuk mengetahui kondisi lereng di sekitar kampus berdasarkan karakteristik geomekanik. Berdasarkan hasil pengamatan, sudut lereng di daerah penelitian didominasi lereng curam hingga terjal. Tingkat kekerasan batuan didominasi oleh batuan keras dengan estimasi kekerasan 50-100 MPa. Hasil Rock Mass Rating didominasi oleh batuan kategori batuan baik (good rock). Hasil perhitungan Slope Mass Rating menunjukkan sudut lereng maksimum yang dapat dibentuk antara $52-75^{\circ}$. Tingkat deformasi dan proses pelapukan yang intensif akan mengurangi tingkat kekuatan massa batuan di masa depan. Beberapa kemunculuan jatuhan batu atau longsoran batu adalah contohnya. Di samping itu, beberapa aktivitas tambang lokal terbuka dekat kaki lereng kampus perlu mendapatkan perhatian, apakah akan berakibat terhadap munculannya longsoran batuan di area kampus ini atau tidak.
\end{abstract}

Kata kunci: rock mass rating, slope mass rating, batugamping, Formasi Rajamandala 


\section{INTRODUCTION}

PPSDM Geominerba field campus is administratively located in Gunung Masigit Village, Padalarang District, West Java Province (Figure 1). This area is located approximately $30 \mathrm{~km}$ west of Bandung as the capital city of this province. The campus is located on a hillop, in the middle of the limestone mining area. The northern part of the campus refers to a cave, namely Guha Pawon and a rock park. The road access to the main campus area follows the morphological form. This area is available within the Oligo-Miocene Rajamandala Formation, which is rich in light-colored, massive limestone, which cannot be separated from the abundant large foraminifera (Sudjatmiko, 1973). This formation was preceded by transgressive black shales of the Early Oligocene Batuasih Formation and overlies the underlying sequence with a slight unconformity (Koesoemadinata and Siregar, 1984). This formation was overlaid by a thick sequence of Miocene turbidites of Citarum Formation and volcanic debris flows or volcanic breccia of Saguling Formation, Bantargadung Formation, and Cantayan Formation with intercalated shallow marine deposits in Late Miocene of Cinalang Formation and intruded by Pliocene volcanic and later covered by Quaternary Volcanics (Koesoemadinata and Siregar, 1984).

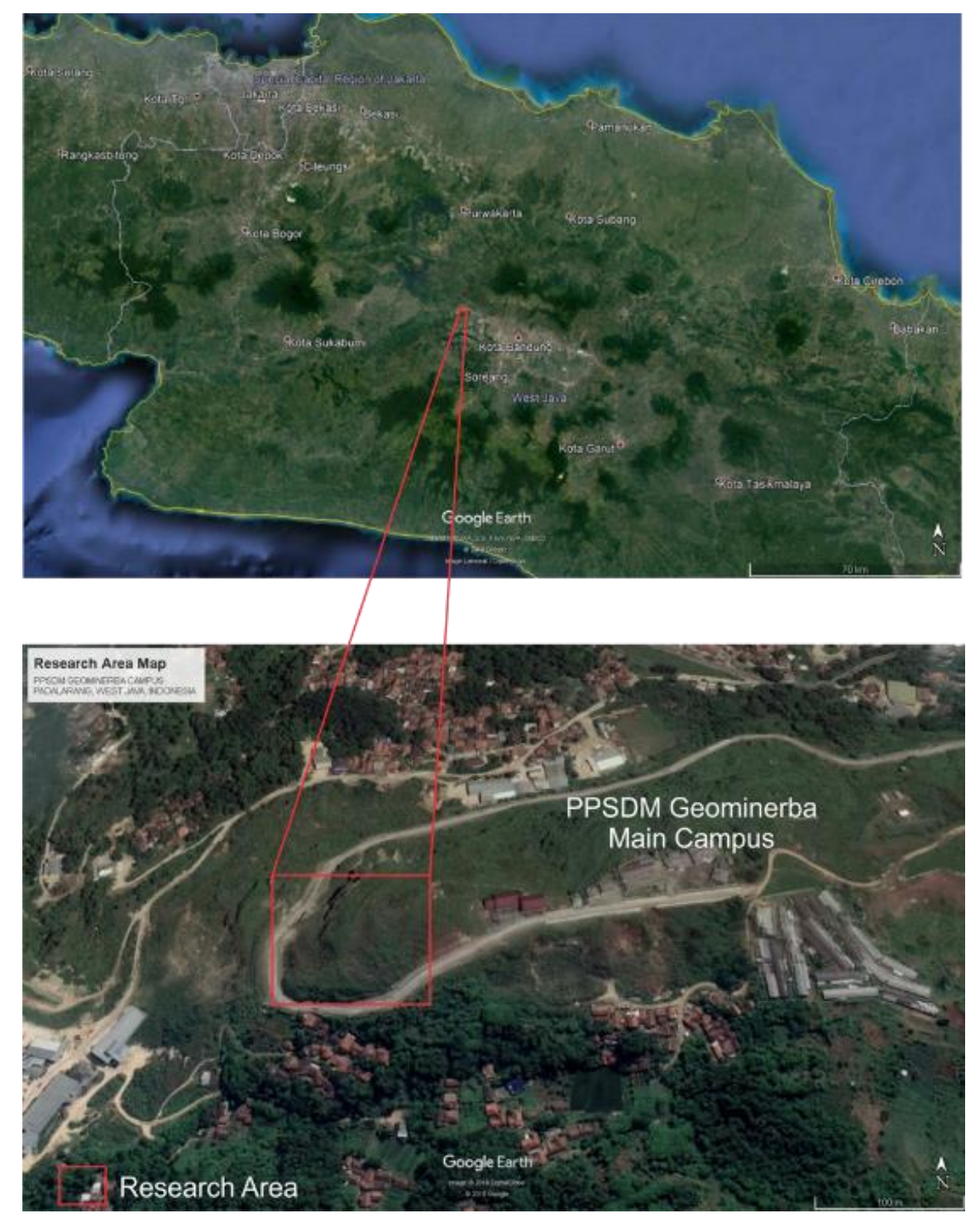

Figure 1. The PPSDM Geominerba campus, Padalarang, West Java 
This Rajamandala Limestone is spread well from Cikamuning on the eastern part to Sanghiangtikoro on the western part. The member of Rajamandala Formation was formed by (1) planktonic packstonewackestone, (2) Lepidocyclina packstone facies (3) rudstone facies (4) boundstone facies and Miliolid packstone facies (Siregar and Mulyadi, 2007). This limestone is part of the Facies Miliolid Packstone (Siregar and Mulyadi, 2007). This facies is formed by layered gray packstone, coarse texture, and is formed by Miliollid, Alveolinid, and Orbitoid. It was deposited in surge channel, lagoon to back reef environment. The tectonic setting in this area is controlled by Rajamandala thrust fault that connected to Cimandiri thrust fault, which has the same pattern as Meratus Lineament. Several locations were strike-slip fault (Martodjojo, 2003).

Some previous works on rock mass rating (RMR) were carried out in this Rajamandala Formation. Zakaria (2005) focuses on cut slope and environmental management. The correction on slope mass rating (SMR) was conducted by Zakaria (2013) and the correlation between RMR and SMR was studied by Zakaria et al. (2013).

The preliminary study of RMR and SMR on the Rajamandala Mine Area was conducted by Prasetya et al. (2015), and Fauziyyah et al. (2015) analyzed the cut slope tilting angle analysis. Modification of SMR was also studied by comparing Rajamandala and Halang Formation by Zakaria et al. (2015). However, these previous studies locations are not in the campus area. This paper would give recent RMR condition in a specific area in the campus area.

The research objective is to obtain a preliminary study about the cut slope hill condition using an RMR classification. The RMR is a well-known method to obtain rock mass data. This RMR is then correlated with the SMR, which to suggest the slope angle recommendation. This recommendation is then compared to the recent slope angle condition.

\section{METHODOLOGY}

Based on discontinuity density of the outcrops, the observation site was divided into 8 segments with interval of measuring section is 1-2 $\mathrm{m}$. Each section was observed based on the Bieniawski RMR classification method.

The main features of the RMR methods were uniaxial compressive strength, rock quality designation, spacing of discontinuities, condition of discontinuities, groundwater conditions, and orientation of discontinuities, rock and soil strength classification Brown (1981) in Abbas and Konietzky (2017), as shown in Table 1.

The rock quality designation (RQD) was determined by scan-line measurement (Hudson and Harrison, 1997 cited in Soufi et al., 2018) on field outcrop by equation:

$R Q D=100(0.1 \lambda+1) e^{-0.1 \lambda}$

where $\lambda$ is scan-line measurement joint/meter.

The RMR based on Bieniawski (as cited in (Zakaria et al., 2015)) can be seen in Table 2.

The application of RMR in slope stability known as SMR was presented by Laubscher (1975), Hall (1985), Orr (1992) in (Djakamihardja, 2009).

Orr (1992) gave RMR and SMR correlation as follows

$\mathrm{SMR}=35 \ln \mathrm{RMR}-71$

While Hall (1985) gave SMR correlation as follows

$\mathrm{SMR}=0,65 \mathrm{RMR} 25$

and Laubscher (1975) cited in Prasetya et al. (2015) gave a correlation on Table 3. 
Table 1. The rock and soil strengths classification (Brown (1981) cited in Abbas and Konietzky (2017))

\begin{tabular}{|c|c|c|c|}
\hline Grade & Description & Field Identification & $\begin{array}{l}\text { Approx. Range of } \\
\text { Uniaxial } \\
\text { Compressive } \\
\text { Strength (Mpa) }\end{array}$ \\
\hline R6 & $\begin{array}{l}\text { Extremely Strong } \\
\text { Rock }\end{array}$ & $\begin{array}{l}\text { Specimen can only be chipped with geological } \\
\text { hammer }\end{array}$ & $>250$ \\
\hline R5 & Very Strong Rock & $\begin{array}{l}\text { Specimen requires many blows of geological } \\
\text { hammer to fracture it }\end{array}$ & $100-250$ \\
\hline $\mathrm{R} 4$ & Strong Rock & $\begin{array}{l}\text { Specimen requires more than one blows of } \\
\text { geological hammer to fracture it }\end{array}$ & $50-100$ \\
\hline R3 & Medium Strong Rock & $\begin{array}{l}\text { Cannot be scraped or peeled with a pocket knife, } \\
\text { specimen can be fractured with single firm blow of } \\
\text { geological hammer }\end{array}$ & $25-50$ \\
\hline $\mathrm{R} 2$ & Weak Rock & $\begin{array}{l}\text { Can be peeled by a pocket knife with difficulty, } \\
\text { shallow indentations made by firm blow with point } \\
\text { of geological hammer }\end{array}$ & $5-25$ \\
\hline $\mathrm{R} 1$ & Very Weak Rock & $\begin{array}{l}\text { Crumbles under firm blows with point of geological } \\
\text { hammer and can be peeled by a pocket knife }\end{array}$ & $1-5$ \\
\hline Ro & Extremely Weak Rock & Indented by thumbnail & $0.25-1$ \\
\hline S6 & $\begin{array}{l}\text { Hard Clay/ Extremely } \\
\text { Weak Rock }\end{array}$ & Indented with difficulty by thumbnail & $>0.5$ \\
\hline S5 & Very Stiff Clay & Readily indented by thumbnail & $0.25-0.5$ \\
\hline S4 & Stiff Clay & $\begin{array}{l}\text { Readily indented by thumbnail but penetrated only } \\
\text { with great difficulty }\end{array}$ & $0.1-0.25$ \\
\hline S3 & Firm Clay & $\begin{array}{l}\text { Can be penetrated several inches by thumb with } \\
\text { moderate effort }\end{array}$ & $0.05-0.1$ \\
\hline S2 & Soft Clay & Easily penetrated several inches by thumb & $0.025-0.05$ \\
\hline S1 & Very Soft Clay & Easily penetrated several inches by thumb & $<0.025$ \\
\hline
\end{tabular}

Table 2. Rock mass rating system modified from Bieniawski (1989)

\begin{tabular}{|c|c|c|c|c|c|c|}
\hline \multicolumn{2}{|c|}{ Parameter } & \multicolumn{5}{|c|}{ Range of values } \\
\hline $\begin{array}{c}\text { Strength of } \\
\text { intact rock } \\
\text { material }\end{array}$ & $\begin{array}{l}\text { Uniaxial } \\
\text { comp. } \\
\text { strength }\end{array}$ & $>250 \mathrm{MPa}$ & $\begin{array}{c}100-250 \\
\mathrm{MPa}\end{array}$ & $\begin{array}{c}50-100 \\
\mathrm{MPa}\end{array}$ & 25-50 MPa & $\begin{array}{r}10-25 \quad 3-10 \\
\text { (unit MPa) }\end{array}$ \\
\hline \multicolumn{2}{|c|}{ Rating } & 15 & 12 & 7 & 4 & 2 \\
\hline \multicolumn{2}{|c|}{$\begin{array}{l}\text { RQD (Rock Quality } \\
\text { Designation) }\end{array}$} & $90-100 \%$ & $74-90 \%$ & $50-75 \%$ & $25-50 \%$ & $<25 \%$ \\
\hline \multicolumn{2}{|c|}{ Rating } & 20 & 17 & 13 & 8 & 3 \\
\hline \multicolumn{2}{|c|}{$\begin{array}{c}\text { Spacing of } \\
\text { discontinuities }\end{array}$} & $>200 \mathrm{~cm}$ & $60-200 \mathrm{~cm}$ & $20-60 \mathrm{~cm}$ & $6-20 \mathrm{~cm}$ & $<6 \mathrm{~cm}$ or $<60 \mathrm{~mm}$ \\
\hline \multicolumn{2}{|c|}{ Rating } & 20 & 15 & 10 & 8 & 5 \\
\hline \multicolumn{2}{|c|}{$\begin{array}{l}\text { Condition of } \\
\text { discontinuities }\end{array}$} & $\begin{array}{c}\text { Very rough } \\
\text { surfaces Not } \\
\text { continuous No } \\
\text { separation } \\
\text { unweathered } \\
\text { wall rock (hard } \\
\text { wall) } \\
\end{array}$ & $\begin{array}{l}\text { Slightly rough } \\
\text { surfaces } \\
\text { separation } \\
<1 \text { mm Slightly } \\
\text { weathered wall } \\
\text { (hard wall) }\end{array}$ & $\begin{array}{l}\text { Slightly rough } \\
\text { surfaces } \\
\text { separation } \\
<1 \mathrm{~mm} \text { Highly } \\
\text { weathered } \\
\text { wall (soft wall) }\end{array}$ & $\begin{array}{c}\text { slickensides } \\
\text { surfaces of } \\
\text { gouge <5 mm } \\
\text { thick or } \\
\text { Separation 1- } \\
5 \mathrm{~mm} \\
\text { continuous }\end{array}$ & $\begin{array}{l}\text { Soft gouge } \\
>5 \mathrm{~mm} \text { thick or } \\
\text { separation } \\
>5 \mathrm{~mm} \\
\text { continuous }\end{array}$ \\
\hline \multicolumn{2}{|c|}{ Rating } & 30 & 25 & 20 & 10 & 0 \\
\hline $\begin{array}{l}\text { Ground } \\
\text { water }\end{array}$ & $\begin{array}{c}\text { General } \\
\text { conditions }\end{array}$ & Completely & Dry & Wet & Dripping & Flowing \\
\hline \multicolumn{2}{|c|}{ Rating } & 15 & 10 & 7 & 4 & 0 \\
\hline \multicolumn{2}{|c|}{ Rating } & $100-81$ & $80-61$ & $60-41$ & $40-21$ & $<21$ \\
\hline \multicolumn{2}{|c|}{ Class Number } & I & II & III & IV & $\mathrm{V}$ \\
\hline \multicolumn{2}{|c|}{ Description } & ery good rock & Good rock & Fair rock & Poor rock & Very poor rock \\
\hline
\end{tabular}

Source: Engineering Rock Mass Classifications : A Complete Manual for Engineers and Geologists in Mining, Civil, and Petroleum Engineering, (Bieniawski, 1989) 
Preliminary Geomechanical Analysis on Limestones in PPRSDM Geominerba ... Irvan Sophian et al.

Table 3. Slope mass rating ( Laubscher (1975) in Prasetya et al. (2015))

\begin{tabular}{ccc}
\hline RMR & Description RMR for the quality of rock & $\begin{array}{c}\text { Recommended slope } \\
\text { angle }\left(^{\circ}\right.\end{array}$ \\
\hline $81-100$ & Very good rock & 75 \\
$61-80$ & Good rock Fairly rock Poorly rock & 65 \\
$41-60$ & Very poorly rock & 55 \\
$21-40$ & Poorly Rock & 45 \\
$0-20$ & Very Poorly Rock & 35 \\
\hline
\end{tabular}

Source: Distinction in rock mass (Laubscher, 1975)

\section{RESULTS AND DISCUSSION}

Based on the field observation, the rockslope within the area was dominated by a very steep slope angle. The slope degree could reach more than $75^{\circ}$ in several sites that can be categorized as an extremely steep slope (Figure 2) according to Van Zuidam slope classification (Triandanu, Alfan and Muslim, 2016). Some slopes were formed by human excavation and blasting after the opening of the road to the main campus on the top of the hill. These slopes were formed by the massive and compact white to grey crystalline limestone and wackestone to packstone according to Dunham Carbonate Rock Classification with discontinuity forms by joints (Siregar and Mulyadi, 2007).

Based on the field test of uniaxial compressive strength by Brown (1981) in
Abbas and Konietzky (2017), the rock strength distribution in this campus area can be shown in Figure 4. The limestone strengths in this research area are categorized into the medium to very strong rock. The strong rock slightly dominates the limestone rock strength with approximate strength 50-100 MPa. This outcrop requires many blows to fracture it. The low porous crystalline limestone could be one factor that causes this strong rock classification. The RMR distribution is shown in Figure 5.

Figure 5 shows that the RMR class in the research area is dominated by class 2 or a good rock (Figure 3 ), ranging RMR value from $61-80$. Whereas class 1 or rock that is very good with an RMR value starting from $81-100$ is available only in two research locations. The correlation between the RMR and SMR is described in Appendix 1.

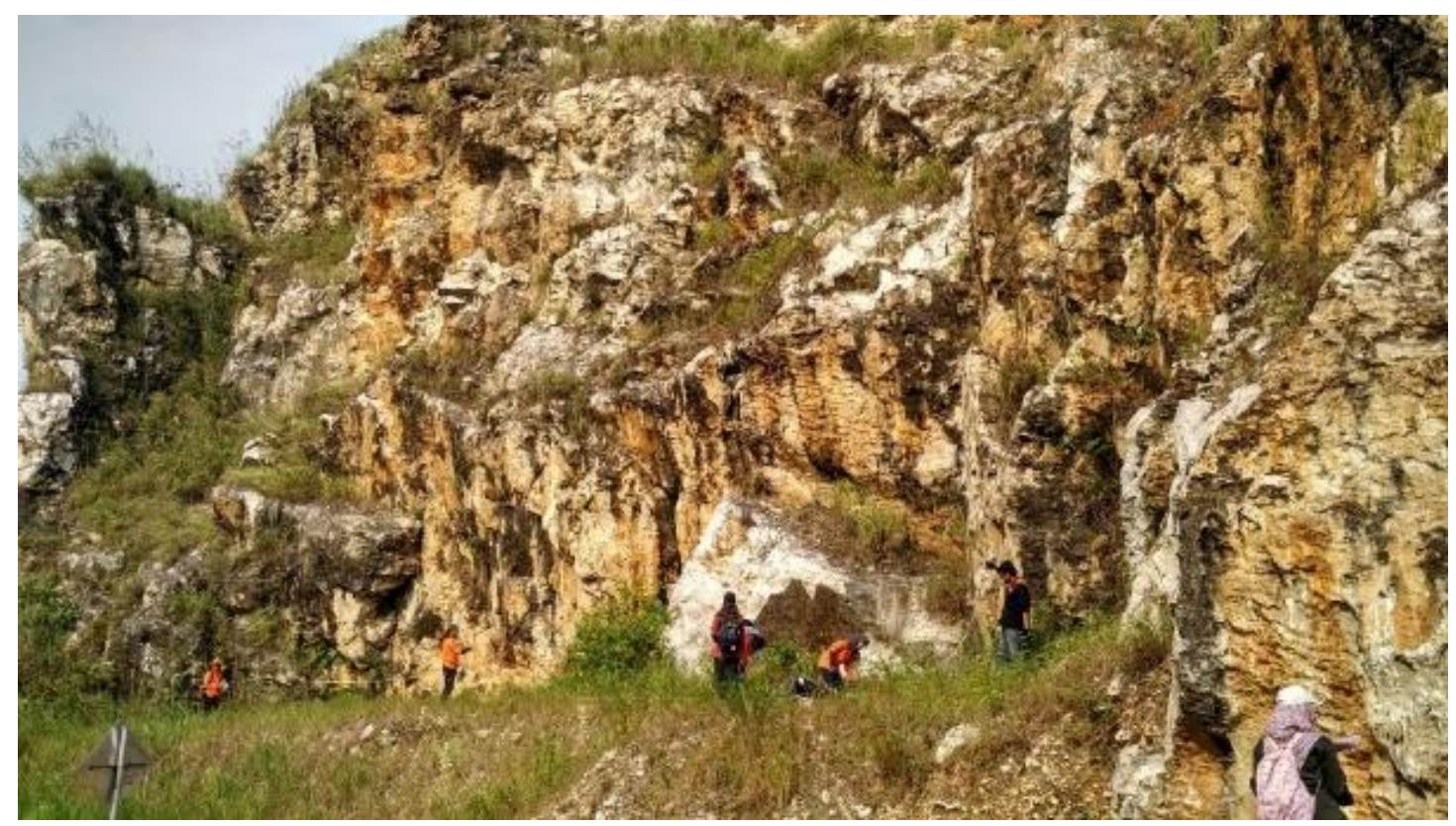

Figure 2. A common outcrop found in PPDSM Geominerba area with an extremely steep slope 


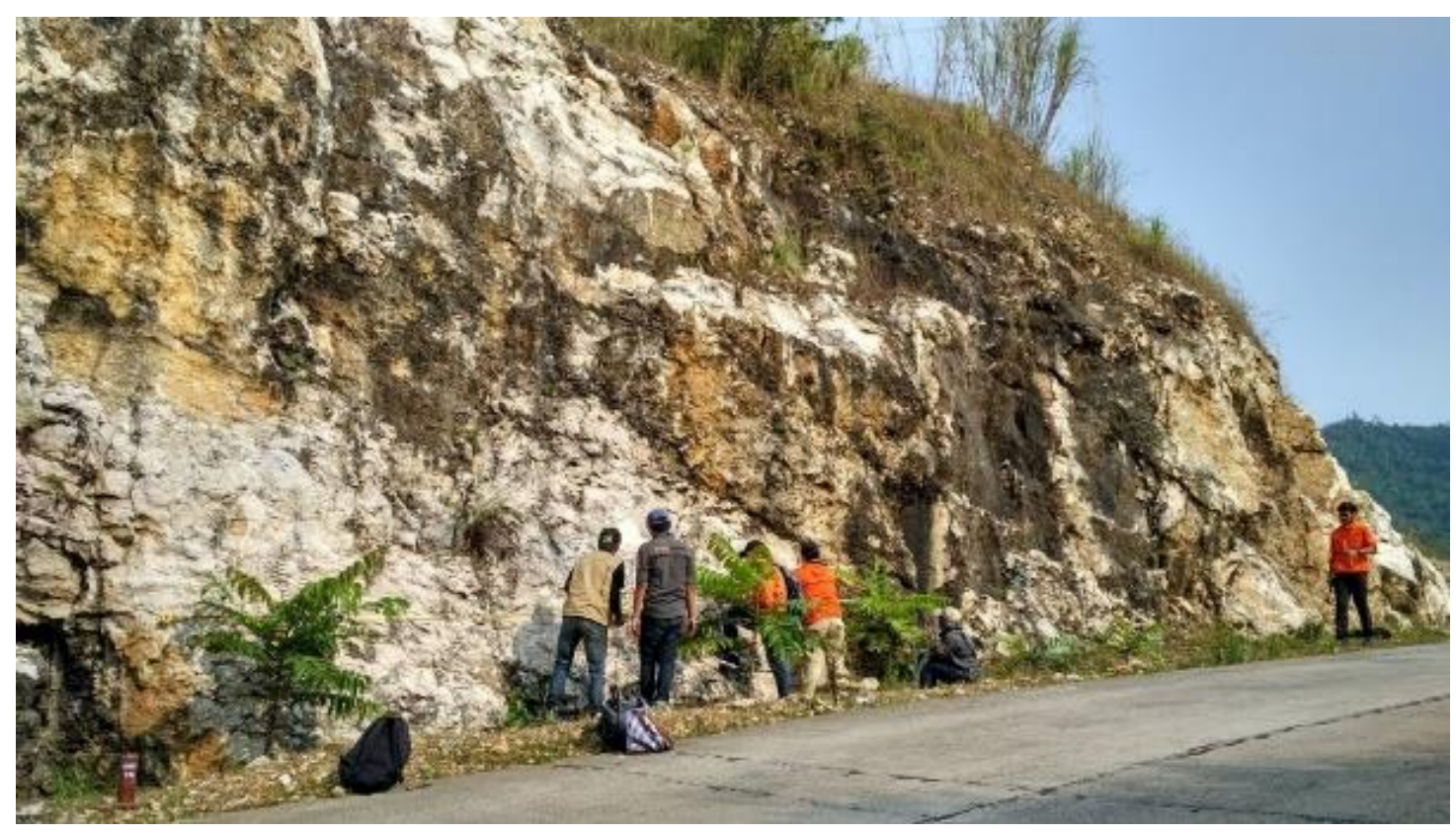

Figure 3. Analyzing the rock mass rating on Segment B

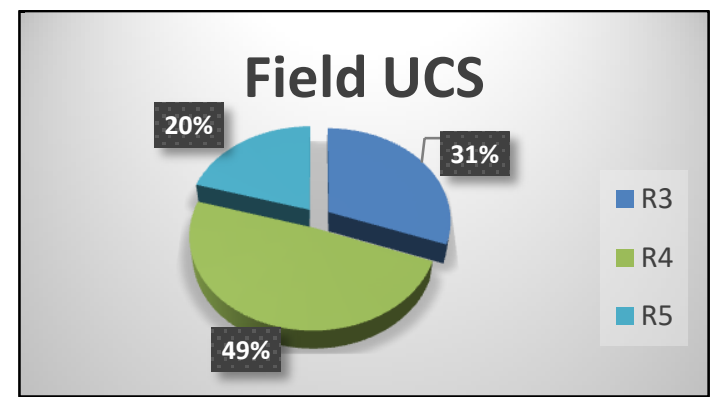

Figure 4. Rock strength distribution

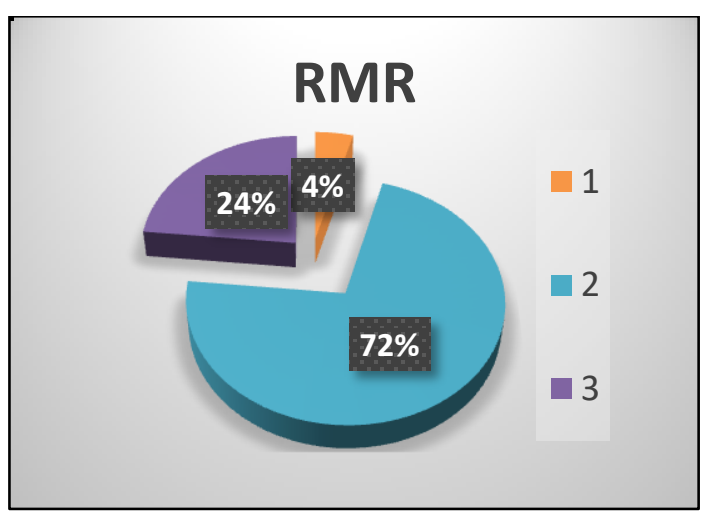

Figure 5. Distribution of RMR class in PPSDM Geominerba area

Based on the results of the SMR used by the Laubscher (1975) method, the recommended optimal angle is lower than the methods of Hall (1985) and Orr (1992) as stated by Prasetya et al., 2015). However, the Hall method shows lower angle suggestions if the RMR is below 50 . The class 3 RMR slope angle suggestion is between $52-55^{\circ}$, and the class 2 RMR slope angle suggestion is between $55-65^{\circ}$, and the class $1 \mathrm{RMR}$ slope angle in $75^{\circ}$ is still acceptable. The SMR calculation results in segment $A$ show that the maximum slope angle that can be formed is between $52-75^{\circ}$. The low angle result is caused by an intensive discontinuity condition on the slope face. However, the higher angle result is caused by less intensive discontinuity condition and stronger rock strength.

The steep slope angle can be formed by a good rock. The good rock is indicated by the level of hardness and the amount of fracture.

These fracture fields are formed due to the deformation process that occurs in the study area. These fracture fields can increase as a result of being affected by mining activities using a blasting method.

However, this analysis was used in the worst condition. The weathering effect would be intensively decrease the strength of the rock mass in the future. Several rock fall occurrences on this research area are evident. 


\section{CONCLUSIONS AND SUGGESTION}

The slope formation is determined by the quality of the rock. The difference in RMR (limestone) in the campus area is determined by the discontinuous field due to the deformation process. The recommended slope angle should use the smallest SMR results so that it can accommodate all slopes. Further geomechanics and geotechnical analysis are needed since there was several evident of rock fall occurrences in this research area.

\section{ACKNOWLEDGEMENT}

We would like to thank The Head of PPSDM Geominerba Bandung for his permission to collect field data in the Padalarang Campus.

\section{REFERENCES}

Abbas, S. M. and Konietzky, H. (2017) 'Rock mass classification systems', in Introduction to Geomechanics. 09/2017 Ed. Freiberg: Technical University Freiberg, pp. 1-48. Available at: https://www.researchgate.net/publication /277504261_Rock_Mass_Classification_ Systems.

Bieniawski, Z. T. (1989) Engineering rock mass classifications: a complete manual for engineers and geologists in mining, civil, and petroleum engineering. John Wiley \& Sons.

Brown, E. T. (1981) Rock characterization testing and monitoring: ISRM suggested methods. Pergamon Press.

Djakamihardja, A. S. (2009) 'The analysis of rock mass characteristics used for design on slope cutting at sections of Liwa Roadway, Sumatera, Indonesia', Jurnal RISET Geologi dan Pertambangan, 19(1), pp. 25-33.

doi: 10.14203/risetgeotam2009.v19.20.

Fauziyyah, F., Jazmi, G., Ibrahim Alhanif, M., Prabowo, T., Chandra, R., Narendra Utomo, R., Prianda, Y. and Zakaria, Z. (2015) Cut slope tilting angle analysis using rock mass rating and slope mass rating on hill I and II, Padalarang, Indonesia. Available at:

https://www.researchgate.net/publication /282971835_Cut_Slope_Tilting_Angle_A nalysis_Using_Rock_Mass_Rating_and _Slope_Mass_Rating_on_Hill_I_and_II_
Padalarang_Indonesia.

Hall, B. E. (1985) 'Plenary estimation of slope angles', in Symp. on Rock Mass Characteristics. Johannesburg: South African National group on Rock Mechanics, pp. 120-121.

Hudson, J. A. and Harrison, J. P. (1997) Engineering rock mechanics. 1st Ed. Elsevier. doi: 10.1016/B978-0-08-0438641.X5000-9.

Koesoemadinata, P. and Siregar, S. (1984) 'Reef facies of the Rajamandala Formation, West Java', in Proceedings Indonesian Petroleum Association, 13th Annual Convention. Indonesian Petroleum Association, pp. 1-18. Available at: https://www.researchgate.net/publication /286783887_Reef_facies_of_the_Rajam andala_Formation_West_Java.

Laubscher, D. H. (1975) 'Distinction in rock mass', Coal Gold and Base Minerals of South Africa, 23(6), pp. 37-50.

Martodjojo, S. (2003) Evolusi cekungan Bogor, Jawa Barat. Institut Teknologi Bandung.

Orr, C. M. (1992) 'Assessment of rock slope stability using Rock Mass Rating (RMR) systems', in The AusIMM Proceedings, pp. 25-29.

Prasetya, I., Narenda, R., Wiramsya, A., Sophian, I. and Muslim, D. (2015) 'RMR and SMR as slope stability preliminary studies of Rajamandala limestones mine area', in 10th Asian Regional Conference of IAEG. Kyoto: IAEG, pp. 1-5. Available at:

http://www.jseg.or.jp/2015ARC/data/TP3 /Tp3-P08_1083122_1509103.pdf.

Siregar, M. S. and Mulyadi, D. (2007) 'Fasies dan diagenesa formasi Rajamandala di daerah Padalarang, Jawa Barat', in Proseding Seminar Geoteknologi Kontribusi IImu Kebumian Dalam Pembangunan Berkelanjutan. Bandung: Geoteknologi LIPI, pp. 19-24.

Soufi, A., Bahi, Lahcen, Ouadif, L. and Kissai, J. E. (2018) 'Correlation between rock mass rating, Q-system and rock mass index based on field data', MATEC Web of Conferences. Edited by A. Diouri et al., 149 , p. 02030. doi: 10.1051/matecconf/201814902030.

Sudjatmiko (1973) 'Peta geologi lembar Cianjur, Jawa, Indonesia'. Bandung: Pusat Survey Geologi, p. 1. 
Triandanu, N., Alfan, I. and Muslim, D. (2016) 'Surface geology characteristic and its influence to landslide potential in Cisokan drainage pattern, West Bandung, Indonesia', International Journal of Structural and Civil Engineering Research, 5(2), pp. 147150. Available at:

http://www.ijscer.com/index.php?m=cont ent $\& c=$ inde $\&$ $a=$ show $\&$ catid $=137 \&$ id $=25$ 7.

Zakaria, Z. (2005) 'Cut slope and environmental management in limestone second hill formation Rajamandala, Citatah, Padalarang, West Java', Bulletin of Scientific Contribution, 3(1).

Zakaria, Z., Muslim, D., Sophian, I. and Anisuzzaman, M. (2013) 'Correlation between RMR and SMR based on field data: A case study in limestone mining area in Citatah, West Java, Indonesia', International Journal of Chemical, Environmental \& Biological Sciences
(IJCEBS), 1(1), pp. 149-152. Available at:

http://www.isaet.org/proceeding.php?cati $\mathrm{d}=131 \&$ type $=3 \&$ mode $=$ detail .

Zakaria, Z. (2013) 'Koreksi pembobotan massa lereng pada desain lereng kupasan stabil di Pasir Pabeasan, formasi batugamping Rajamandala, Padalarang, Jawa Barat', in 13th Simposium Kebudayaan Indonesia Malaysia (SKIM). Bandung: Universitas Padjadjaran, p. 52. Available at: https://studylib.net/doc/8823638/prosidin g-skim-xiii---simposium-kebudayaanindonesia.

Zakaria, Z., Muslim, D., Jihadi, L. H. and Sabila, Z. S. (2015) 'Modification of slope mass rating for stable slope design', in 10th Asian Regional Conference of IAEG. Kyoto: Japan Society of Engineering Geology, pp. 1-6. Available at: http://www.jseg.or.jp/2015ARC/data/TP3 /Tp3-25_1083743_1509874.pdf. 
Preliminary Geomechanical Analysis on Limestones in PPRSDM Geominerba ... Irvan Sophian et al.

APPENDIX I

Correlation between RMR and SMR

\begin{tabular}{|c|c|c|c|c|c|}
\hline \multirow{2}{*}{ Segment } & \multirow{2}{*}{ RMR } & \multirow{2}{*}{ Kelas } & \multicolumn{3}{|c|}{ SMR } \\
\hline & & & Hall & Orr & Laubscher \\
\hline $\mathrm{A} 1$ & 53 & 3 & 59 & 62 & 55 \\
\hline A1 & 41 & 3 & 52 & 59 & 55 \\
\hline A1 & 60 & 3 & 64 & 72 & 55 \\
\hline $\mathrm{A} 1$ & 45 & 3 & 54 & 62 & 55 \\
\hline $\mathrm{A} 1$ & 55 & 3 & 61 & 69 & 55 \\
\hline A1 & 49 & 3 & 57 & 65 & 55 \\
\hline $\mathrm{A} 2$ & 82 & 1 & 78 & 82 & 75 \\
\hline $\mathrm{A} 2$ & 71 & 2 & 71 & 78 & 65 \\
\hline $\mathrm{A} 2$ & 82 & 1 & 75 & 81 & 75 \\
\hline $\mathrm{A} 2$ & 79 & 2 & 76 & 82 & 65 \\
\hline $\mathrm{A} 2$ & 74 & 2 & 73 & 80 & 65 \\
\hline $\mathrm{A} 2$ & 71 & 2 & 71 & 78 & 65 \\
\hline A3 & 67 & 2 & 69 & 76 & 65 \\
\hline A3 & 66 & 2 & 68 & 76 & 65 \\
\hline A3 & 68 & 2 & 69 & 77 & 65 \\
\hline A4 & 71 & 2 & 71 & 78 & 65 \\
\hline A4 & 63 & 2 & 66 & 74 & 65 \\
\hline A4 & 74 & 2 & 73 & 80 & 65 \\
\hline A5 & 65 & 2 & 67 & 75 & 65 \\
\hline A5 & 76 & 2 & 74 & 81 & 65 \\
\hline B1 & 63 & 2 & 66 & 74 & 65 \\
\hline B1 & 70 & 2 & 71 & 78 & 65 \\
\hline B1 & 72 & 2 & 72 & 79 & 65 \\
\hline B1 & 54 & 2 & 60 & 63 & 55 \\
\hline B1 & 58 & 2 & 63 & 71 & 55 \\
\hline B1 & 67 & 2 & 69 & 76 & 65 \\
\hline B1 & 75 & 2 & 74 & 80 & 65 \\
\hline B1 & 76 & 2 & 74 & 81 & 65 \\
\hline B1 & 72 & 2 & 72 & 79 & 65 \\
\hline $\mathrm{B} 1$ & 77 & 2 & 75 & 81 & 65 \\
\hline B1 & 65 & 2 & 67 & 75 & 65 \\
\hline B1 & 61 & 2 & 65 & 73 & 65 \\
\hline B1 & 54 & 2 & 60 & 63 & 55 \\
\hline $\mathrm{B} 1$ & 66 & 2 & 68 & 76 & 65 \\
\hline $\mathrm{B} 1$ & 65 & 2 & 67 & 75 & 65 \\
\hline B1 & 69 & 2 & 70 & 77 & 65 \\
\hline $\mathrm{B} 1$ & 69 & 2 & 70 & 77 & 65 \\
\hline $\mathrm{B} 1$ & 64 & 2 & 67 & 75 & 65 \\
\hline B1 & 65 & 2 & 67 & 75 & 65 \\
\hline B3 & 45 & 3 & 54 & 62 & 55 \\
\hline B3 & 48 & 3 & 56 & 64 & 55 \\
\hline B3 & 45 & 3 & 54 & 62 & 55 \\
\hline B3 & 66 & 2 & 68 & 76 & 65 \\
\hline B3 & 74 & 2 & 73 & 80 & 65 \\
\hline B4 & 64 & 2 & 67 & 77 & 65 \\
\hline B4 & 71 & 2 & 71 & 80 & 65 \\
\hline B5 & 59 & 2 & 64 & 72 & 55 \\
\hline B5 & 73 & 2 & 72 & 79 & 65 \\
\hline B5 & 64 & 2 & 67 & 75 & 65 \\
\hline
\end{tabular}


